UNDERGRADUATE RESEARCH IN NATURAL AND CLINICAL SCIENCE AND TECHNOLOGY (URNCST) JOURNAL Read more URNCST Journal articles and submit your own today at: https://www.urncst.com

\title{
Genetic Modification of the HSP90 Gene Using CRISPR- Cas9 to Enhance Thermotolerance in T. Suecica
}

Joy Xu, BHSc Student [1], Vedish Soni, BHSc Student [1], Meera Chopra, BHSc Student [1], Olsen Chan, BHSc Student [1]

[1] Faculty of Health Sciences, McMaster University, Hamilton, Ontario, L8S 4L9

*Corresponding Author: xuj169@mcmaster

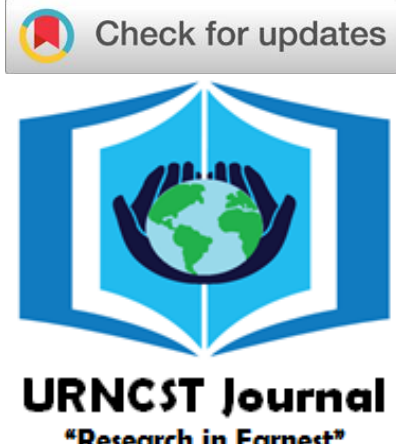

"Research in Earnest"

\begin{abstract}
Phytoplankton are marine microorganisms that play a key role in the production of oxygen and serve as the foundation of the marine food chain. Over the past century, the population of phytoplankton has declined significantly with the onset of climate change. Although phytoplankton have the capacity to adapt to rising ocean temperatures, rapid environmental changes, including increased top-down control and thermal stratification, reduce populations before adaptations are incorporated into the genome. To enhance survival rates, thermotolerance in common algal strains can be enhanced through increased expression of the conserved Heat Shock Protein 90 (HSP90). Trials will be conducted on the common algal species, Tetraselmis suecica (T. suecica), for its considerable size, photosynthetic rate, and nutrient-rich properties. Thermotolerance will be augmented by splicing the $H S P 90$ gene into the $T$. suecica metallothionein $(M t)$ promoter using CRISPR-Cas9. A period of incubation in a copper sulphate solution ensures $M t$ promoter stimulation, thereby increasing HSP90 expression. The efficacy of the proposed methods will be measured by comparing HSP90 protein production between transgenic and wild-type T. suecica cultures. The genomic incorporation of the modified HSP9O gene enables future populations to exhibit thermotolerance in the presence of heavy metals in the ocean beyond its basal level of expression. By accelerating the adaptation of thermotolerance, the overall fitness of $T$. suecica can be increased to re-establish its population under warmer oceanic conditions. By applying similar methods to other phytoplankton, the repopulation of various species can increase biodiversity and global net primary productivity.
\end{abstract}

Keywords: Heat Shock Protein 90 (HSP90); metallothionein (Mt); phytoplankton; climate change; CRISPR-Cas 9; thermotolerance

\section{Introduction}

Phytoplankton produce $70 \%$ of the world's oxygen, despite accounting for $1 \%$ of global photosynthetic biomass [1-3]. As a food source for numerous aquatic species, this producer serves a foundational role in the marine food web [4]. Although phytoplankton are capable of mitigating the effects of climate change by fixing between 30 to 50 billion metric tons of carbon each year, climate change has increased oceanic temperatures beyond the typical living conditions of phytoplankton $[1,5]$. This has resulted in a $40 \%$ population decline since 1950 [6-7]. In response to climate change, species are able to modify their reproductive habits and geographical dispersion. Thus, phytoplankton can withstand incremental increases in temperature [8]. However, it is predicted that organisms would not be able to adapt rapidly enough to resist the effects of climate change, notably elevated levels of topdown control and thermal stratification [8]. Besides rising oceanic temperatures, increased top-down control further amplifies the predation of primary producers, resulting in the decreased accumulation of biomass. This effect may significantly decreasing the phytoplankton population, preventing the inheritance of genetic mutations that allow for thermal resistance [9]. These marine organisms must also overcome the environmental challenge of thermal stratification, which involves the division of lakes into horizontal layers based on their temperature. Increased thermal stratification has been linked to a decrease in phytoplankton population $[8,10]$.

Within 80 years, the average global ocean surface temperature is estimated to increase by $4^{\circ} \mathrm{C}$ [11-13]. Certain species of phytoplankton, such as Desmodesmus armatus, are capable of tolerating warmer water temperatures due to an intrinsically high expression of the Heat Shock Protein 90 (HSP90) gene [14]. Under stressful conditions, such as increases in temperature, HSP90 chaperone proteins are produced to assist in protein folding [15-17]. This prevents the thermal denaturation of proteins to maintain homeostasis, which improves the thermotolerance of the organism [15-16]. Other common species, notably Tetraselmis suecica, optimally function in temperatures of approximately $18.0^{\circ} \mathrm{C}$ [18-20]. This phytoplankton will need 
UNDERGRADUATE RESEARCH IN NATURAL AND CLINICAL SCIENCE AND TECHNOLOGY (URNCST) JOURNAL Read more URNCST Journal articles and submit your own today at: https://www.urncst.com

to adapt to the onset of warmer conditions in the upcoming decades by becoming more thermotolerant [21]. Since the HSP90 gene is naturally expressed in T. suecica, the adaptation of heat tolerance can be accelerated by genetically modifying this species to increase $H S P 90$ expression [21-22]. With potential mutation rates between 1.1 to $2.5 \%$, CRISPR-Cas9 is an efficient and cost-effective gene-editing tool, which has been used multiple times to edit algal genes in the past [4,23-25]. CRISPR-Cas9 has two major components that allow it to splice genes: single guide RNA (sgRNA), which directs the Cas-9 enzyme to the correct location on the genome and the Cas-9 enzyme, which splices the gene to allow foreign DNA to be inserted [23].

\section{Methods}

To enhance the thermotolerance of $T$. suecica, CRISPR-Cas9 will be used to cut the HSP90 gene and place it next to the $M t$ promoter [26]. The $H S P 90$ gene is a part of a plasmid, called HSP90 $H A$, which will be purchased from a commercial vendor. Under normal conditions, the $M t$ promoter transcribes the conserved metallothionein 1A (Mt1A) gene [27-28]. However, CRISPR-Cas9 will be used to replace the MtlA gene with the HSP90 HA plasmid, thereby activating the $M t$ promoter to produce $H S P 90$ [29].

Due to the toxicity of Cas9 to microalgae, Cas9 ribonucleoproteins (RNPs) will be used to prevent cell death, as they eventually degrade within the cell [30-31]. As this complex is comprised of the Cas9 protein and sgRNA without a vector, gradual degradation is enabled [32]. A Cas-9 RNP is created through the incubation of the Cas-9 protein with sgRNA. The sgRNA that targets the MtlA gene and the Cas9 protein will be purchased from manufacturers, such as ToolGen, Inc [32]. The Cas-9 RNPs will be created through the incubation of $10 \mu \mathrm{g}$ of $\mathrm{sgRNA}$ and $7.5 \mu \mathrm{g}$ of Cas 9 protein at $37^{\circ} \mathrm{C}$ for 30 minutes [32].

To ensure the successful incorporation of the HSP9O gene into microalgal DNA, a traceable marker will be inserted. By splicing HSP90 into a plasmid that codes for antibiotic resistance, the insertion of this plasmid can be tested by treating the host with antibiotics [33]. This is accomplished with a plasmid that contains the code for zeocin antibiotic resistance, $p M O D-z e o$, which will be ligated to the HSP90 HA plasmid using the restriction endonucleases NcoI-Styl and BseRI [34-35]. Using polymerase chain reaction $(\mathrm{PCR})$ at $96^{\circ} \mathrm{C}$, this mutant plasmid will be linearized to create free ends that can bind to $T$. suecica DNA.

The $T$. suecica cells will be placed in 6-well plates and $250 \mathrm{~V}$ will be applied for electroporation [31]. This technique will increase the permeability of cell membranes by placing cells in an electric field [36]. The cells will be transfected with $2.0 \mu \mathrm{g}$ Cas-9 RNP and $0.4 \mu \mathrm{g}$ of the linear HSP9O HA plasmid [37].

These cells will then be moved onto agar plates where they will be incubated in $100 \mu \mathrm{g} / \mathrm{ml}$ of zeocin solution for
16 hours [38]. The surviving cells will contain the $p M O D$ zeo gene and thus the HSP90 gene. These transgenic cells will be referred to as $M t 90$ cells, as they contain the $H S P 90$ gene under the control of the $M t$ promoter. $M t 90$ cells express the $H S P 90$ gene when initiated by the $M t$ promoter.

To test the increased thermotolerance of the transgenic phytoplankton, $50 \mu \mathrm{L}$ samples of the modified cells and wild-type cells will be distributed to 96-well microplates as the experimental and control groups [39]. These wells will be incubated with a $200 \mu \mathrm{M}$ solution of copper sulphate for two hours, followed by a heat-shock of $36^{\circ} \mathrm{C}$ to allow for the distribution of $H S P 90$ [40].

Thermogravimetric analysis (TGA) will test the effects of genetic modification on thermotolerance by measuring sample mass difference over a temperature range of $25^{\circ} \mathrm{C}$ to $45^{\circ} \mathrm{C}$. As increasing mass loss corresponds to population reduction, temperatures with minimal mass loss indicate the optimal temperature range for Mt90 T. suecica strains [41].

\section{Results}

The insertion of the metallothionein-controlled HSP9O gene into $T$. suecica cells is expected to increase HSP9O protein production to induce an increase of thermotolerance up to $4^{\circ} \mathrm{C}$. As one of the most photosynthetically productive organisms, phytoplankton play a vital role in greenhouse gas uptake and oxygen production [42]. Hence, phytoplankton populations must be maintained at an appropriate size for the long-term amelioration of climate change [43].

\section{Discussion}

In a lab setting, experimenters have exquisite control over phytoplankton development with minimal ethical and financial challenges [44]. As a result, laboratory testing will be both feasible and accessible for researchers.

$T$. suecica was chosen as a model organism for its nutritional content, photosynthetic, and reproduction rates [45]. As most organisms possess the conserved HSP9O gene, similar results may also be recreated in other phytoplankton species.

The thermotolerance of $T$. suecica will be increased by inserting the HSP90 gene in the place of the Mt1A gene to be inducible by the $M t$ promoter [40]. This technique will initiate gene expression in the presence of heavy metals. CRISPR-Cas9 genetic modification techniques will be used to splice the HSP90 and Mt1A genes together, as this process is able to target specific eukaryotic DNA sequences with a low error rate [40].

Although no studies to date have performed CRISPRCas9 gene editing on $T$. suecica, researchers have used this technology on similar microalgae, including Phaeodactylum tricornutum [46]. Researchers were able to locate target genes using guide RNAs and insert foreign DNA using the Cas9 complex. As well, the investigators successfully tested for the uptake of the inserted genes, demonstrating that this genetic editing technique can be employed in microalgae [46]. Subsequently, genetic editing in T. Suecica is expected to 
UNDERGRADUATE RESEARCH IN NATURAL AND CLINICAL SCIENCE AND TECHNOLOGY (URNCST) JOURNAL Read more URNCST Journal articles and submit your own today at: https://www.urncst.com

have similar results to the aforementioned studies, allowing for the increased expression of HSP90 in this species.

Copper is an effective inducer of the $M t$ gene with high levels of soft-tissue uptake. Therefore, this metal will be used to initiate $M t 90$ gene expression [47]. However, other heavy metals, including arsenic, cadmium, and lead are also able to induce the expression of $M t 90$ [48].

Research has shown that the aquatic copper concentration required to induce the expression of the $M t$ gene is $5.00 \mu \mathrm{g} / \mathrm{L}$ and several studies have measured concentrations above this level in the Pacific Ocean [49-51]. Thus, the recombinant $M t 90$ will be expressed in transgenic T. suecica in their natural habitat.

The conducted trials may potentially induce thermotolerance by genetically incorporating the modified DNA in future $T$. suecica populations. However, the proliferation of modified phytoplankton must be measured in a laboratory setting prior to their introduction in ecosystems. For these trials, algal species will be incubated through photobioreactors to grow sample colonies [49]. As well, statistical analyses should be performed to estimate the effects of introducing this modified strain to oceanic environments [52]. After comprehensive studies and appropriate alterations, closed-system segments within smaller bodies of water must be designated to simulate the performance of modified $T$. suecica in marine environments [52-53]. Each trial must be performed with caution to minimize biological consequences in ecosystems, such as competition with native species [49]. Depending on the stage of testing, adverse effects resulting from the introduction of the modified $T$. suecica strain must be alleviated through the consideration of additional variables [52]. With the introduction of thermotolerance into the gene pool, algae reproductivity can gradually be re-established to increase oceanic photosynthetic rates.

\section{Conclusion}

The proposed study will determine the thermotolerant capability of genetically modified $T$. suecica. Additional lab testing will be required to observe the impact of these genetically modified phytoplankton on the marine biosphere. With the development of thermoresistant phytoplankton, this study has the potential to initiate a feasible and effective solution to mitigate the consequences of climate change.

\section{List of Abbreviations used}

$M t$ : Metallothionein

HSP90: Heat Shock Protein 90

sgRNA: Single guide ribonucleic acid

DNA: Deoxyribonucleic acid

CRISPR: Clustered Regularly Interspaced Short

Palindromic Repeats

URNCST: Undergraduate Research in Natural and Clinical

Science and Technology

Mt1A: Metallothionein 1A

PCR: Polymerase chain reaction
TGA: Thermogravimetric analysis

\section{Conflicts of Interest}

All article types: The author(s) declare that they have no conflict of interests

\section{Ethics Approval and/or Participant Consent}

This research protocol did not require ethics approval and/or participant consent.

\section{Authors' Contributions}

JX: Made substantial contributions to the design of the study, collected and analysed data, drafted the manuscript, revised the manuscript critically and gave final approval of the version to be published.

VS: Contributed to study design and planning, created the methodology and analysis of data, revised the manuscript critically and gave final approval of the version to be published.

MC: Made contributions to the design of the study, the collection of data and an analysis of the data, revised the manuscript critically, and gave final approval of the version to be published.

OC: Contributed to study design and planning, the interpretation and analysis of collected data, revised the manuscript critically and gave final approval of the version to be published.

\section{Funding}

This study was not funded.

\section{References}

[1] Falkowski PG. The role of phytoplankton photosynthesis in global biogeochemical cycles. Photosynthesis Research. 1994 Mar 1;39(3):235-58. https://doi.org/10.1007/BF00014586

[2] Song L, Jiang Y, Zhao H, Hou M. Acquired thermotolerance in plants. Plant Cell Tissue and Organ Culture. 2012 Dec;111(3):265-76. https://doi.org /10.1007/s11240-012-0198-6

[3] National Geographic. Save the plankton, breathe freely [Internet]. [cited 2019 Nov 22]. Available from: https://www.nationalgeographic.org/activity/save-theplankton-breathe-freely/

[4] Wu ZY, Huang YT, Chao WC, Ho SP, Cheng JF, Liu PY. Reversal of carbapenem-resistance in Shewanella algae by CRISPR/Cas9 genome editing. Journal of Advanced Research. 2019 Jul 1;18:61-9. https://doi.org /10.1016/j.jare.2019.01.011

[5] Falkowski PG, Katz ME, Knoll AH, Quigg A, Raven JA, Schofield O, et al. The evolution of modern eukaryotic phytoplankton. Science. 2004 Jul 16;305 (5682):354-60. https://doi.org/10.1126/science.1095964

[6] Hallegraeff GM. Ocean climate change, phytoplankton community responses, and harmful algal blooms: A formidable predictive challenge. Journal of Phycology. 
UNDERGRADUATE RESEARCH IN NATURAL AND CLINICAL SCIENCE AND TECHNOLOGY (URNCST) JOURNAL Read more URNCST Journal articles and submit your own today at: https://www.urncst.com

2010 Apr;46(2):220-35. $\quad \underline{\text { https://doi.org/10.1111/ }}$ j.1529-8817.2010.00815

[7] Watts S. Global warming is putting the ocean's phytoplankton in danger [Internet]. Pacific Standard. 2017 Dec 29. [cited 2019 Nov 22]. Available from: https://psmag.com/environment/global-warming-isputting-phytoplankton-in-danger

[8] Hoffmann AA, Sgrò CM. Climate change and evolutionary adaptation. Nature. 2011 Feb 24;470(7335): 479-85. https://doi.org/10.1038/nature09670

[9] Jorgensen SE, Fath BD. Encyclopedia of ecology. Newnes; 2014 Nov 3.

[10] Ruardij P, Van Haren H, Ridderinkhof H. The impact of thermal stratification on phytoplankton and nutrient dynamics in shelf seas: A model study. Journal of Sea Research. 1997 Dec 2;38(3-4):311-31. https://doi.org /10.1016/S1385-1101(97)00042-7

[11] McQuatters-Gollop A, Reid PC, Edwards M, Burkill $\mathrm{PH}$, Castellani $\mathrm{C}$, Batten $\mathrm{S}$, et al. Is there a decline in marine phytoplankton? Nature. 2011 Apr 13;472(7342): E6-7. https://doi.org/10.1038/nature09950

[12] Boyce DG, Lewis MR, Worm B. Global phytoplankton decline over the past century. Nature. 2010 Jul;466(7306):591-6. https://doi.org/10.1038/ nature09268

[13] International Union for the Conservation of Nature. Ocean warming [Internet]. 2016. [cited 2019 Nov 22]. Available from: https://www.iucn.org/resources/ issues-briefs/ocean-warming

[14] Herrero C, Cid A, Fabregas J, Abalde J. Yields in biomass and chemical constituents of four commercially important marine microalgae with different culture media. Aquacultural Engineering. 1991;10(2):99-110. https://doi.org/10.1016/0144-8609 (91)90003-3

[15] Wandinger SK, Richter K, Buchner J. The Hsp90 chaperone machinery. Journal of Biological Chemistry. 2008 Jul 4;283(27):18473-7. https://doi.org /10.1074/jbc.R800007200

[16] Young JC, Moarefi I, Hartl FU. Hsp90: A specialized but essential protein-folding tool. Journal of Cell Biology. 2001 Jul 23;154(2):267. https://doi.org /10.1083/jcb.200104079

[17] Hoter A, El-Sabban ME, Naim HY. The HSP90 family: Structure, regulation, function, and implications in health and disease. International Journal of Molecular Science. 2018 Sep;19(9):2560. https://doi.org/10.3390/ijms19092560

[18] Abu-Rezq TS, Al-Musallam L, Al-Shimmari J, Dias P. Optimum production conditions for different highquality marine algae. Hydrobiologia. 1999 May 1;403:97-107. https://doi.org/10.1023/A:1003725626504

[19] Beere HM. The stress of dying: The role of heat shock proteins in the regulation of apoptosis. Journal of Cell Science. 2004 Jan;117(13):2641-51. https://doi.org/ $\underline{10.1242 / j \operatorname{cs} .01284}$

Xu et al. | URNCST Journal (2020): Volume 4, Issue 4

DOI Link: https://doi.org/10.26685/urncst.178
[20] Huang CC, Hung JJ, Peng SH, Chen CNN. Cultivation of a thermo-tolerant microalga in an outdoor photobioreactor: Influences of $\mathrm{CO} 2$ and nitrogen sources on the accelerated growth. Bioresource Technology. 2012 May;11:228-33. https://doi.org/ 10.1016/j.biortech.2012.02.078

[21] Lee MC, Park JC, Yoon DS, Choi H, Kim HJ, Shin $\mathrm{KH}$, et al. Genome-wide characterization and expression of the elongation of very long chain fatty acid (Elovl) genes and fatty acid profiles in the alga (Tetraselmis suecica) fed marine rotifer Brachionus koreanus. Comparative Biochemistry and Physiology Part D: Genomics and Proteomics. 2019 Jun 1;30:17985. https://doi.org/10.1016/j.cbd.2019.03.001

[22] Hoppenrath M, Leander BS. Dinoflagellate phylogeny as inferred from heat shock protein 90 and ribosomal gene sequences. PLoS ONE. 2010;5(10). https://doi.org /10.1371/journal.pone.0013220

[23] Hruscha A, Krawitz P, Rechenberg A, Heinrich V, Hecht J, Haass C, et al. Efficient CRISPR/Cas9 genome editing with low off-target effects in zebrafish. Development. $2013 \quad$ Dec 15;140(24):4982-7. https://doi.org/10.1242/dev.099085

[24] Nymark M, Sharma AK, Sparstad T, Bones AM, Winge P. A CRISPR/Cas9 system adapted for gene editing in marine algae. Scientific Reports. 2016 Apr 25;6:24951. https://doi.org/10.1038/srep24951

[25] Patel VK, Soni N, Prasad V, Sapre A, Dasgupta S, Bhadra B. CRISPR-Cas9 system for genome engineering of photosynthetic microalgae. Molecular Biotechnology. $2019 \quad$ May 28;61:541-61. https://doi.org/10.1007/s12033-019-00185-3

[26] González-Dávila M. The role of phytoplankton cells on the control of heavy metal concentration in seawater. Marine Chemistry. 1995 Feb 1;48(3-4):21536. https://doi.org/10.1016/0304-4203(94)00045-F

[27] Thomas MK, Kremer CT, Klausmeier CA, Litchman E. A global pattern of thermal adaptation in marine phytoplankton. Science. 2012 Nov 23;338(6110): 1085-8. https://doi.org/10.1126/science.1224836

[28] Doney SC. Plankton in a warmer world. Nature. 2006 Dec;444(7120):695-6. https://doi.org/10.1038/444695a

[29] Robinson NJ. Algal metallothioneins: Secondary metabolites and proteins. Journal of Applied Phycology. 1989 Apr 1;1(1):5-18. https://doi.org /10.1007/BF00003530

[30] Hempstead A. CRISPR 101: Ribonucleoprotein (RNP) delivery [Internet]. Addgene. 2018 Sep 6. [cited 2019 Nov 22]. Available from: https://blog.addgene.org /crispr-101-ribonucleoprotein-rnp-delivery

[31] Shin SE, Lim JM, Koh HG, Kim EK, Kang NK, Jeon $\mathrm{S}$, et al. CRISPR/Cas9-induced knockout and knock-in mutations in Chlamydomonas reinhardtii. Scientific Reports. 2016 Jun 13;6(1):1-5. https://doi.org/10.1038/ srep27810 
UNDERGRADUATE RESEARCH IN NATURAL AND CLINICAL SCIENCE AND TECHNOLOGY (URNCST) JOURNAL

Read more URNCST Journal articles and submit your own today at: https://www.urncst.com

[32] Nezbrytskaya IN, Kureyshevich AV. Mechanisms of algae's resistance to elevated temperatures (a review). Hydrobiological Journal 2014;50(2):18-32. https://doi.org/10.1615/HydrobJ.v50.i2.20

[33] Wu ZY, Huang YT, Chao WC, Ho SP, Cheng JF, Liu PY. Reversal of carbapenem-resistance in Shewanella algae by CRISPR/Cas9 genome editing. Journal of Advanced Research. 2019 Jul 1;18:61-9. https://doi.org/10.1016/j.jare.2019.01.011

[34] Osorio H, Jara C, Fuenzalida K, Rey-Jurado E, Vásquez M. High-efficiency nuclear transformation of the microalgae Nannochloropsis oceanica using Tn5 Transposome for the generation of altered lipid accumulation phenotypes. Biotechnology for Biofuels. 2019 Dec 1;12(1):134. https://doi.org/10.1186/s13068019-1475-y

[35] Aoyama M, Agari K, Sun-Wada GH, Futai M, Wada Y. Simple and straightforward construction of a mouse gene targeting vector using in vitro transposition reactions. Nucleic Acids Research. 2005 Mar 22;33(5):e52. https://doi.org/10.1093/nar/gni055

[36] Muñoz CF, de Jaeger L, Sturme MH, Lip KY, Olijslager JW, Springer J, et al. Improved DNA/protein delivery in microalgae - A simple and reliable method for the prediction of optimal electroporation settings. Algal Research. 2018 Jul 1;33:448-55. https://doi.org/10.1016/j.algal.2018.06.021

[37] Zheng Q, Cai X, Tan MH, Schaffert S, Arnold CP, Gong $X$, et al. Precise gene deletion and replacement using the CRISPR/Cas9 system in human cells. Biotechniques. $2014 \quad$ Sep 1;57(3):115-24. https://doi.org/10.2144/000114196

[38] Liu L, Wang Y, Zhang Y, Chen X, Zhang P, Ma S. Development of a new method for genetic transformation of the green alga Chlorella ellipsoidea. Molecular Biotechnology. 2013 Jun;54(2):211-19. https://doi.org/10.1007/s12033-012-9554-3

[39] Tanaka T, Yamakawa N, Koike N, Suzuki J, Mizuno F, Usui M. Behçet's disease and antibody titers to various heat-shock protein 60s. Ocular Immunology and Inflammation. 1999 Jan;7(2):69-74. https://doi.org /10.1076/ocii.7.2.69.4018

[40] Feder JH, Rossi JM, Solomon J, Solomon N, Lindquist $\mathrm{S}$. The consequences of expressing hsp70 in Drosophila cells at normal temperatures. Genes \& Development. 1992;6:1402-13. https://doi.org/10.1101/gad.6.8.1402

[41] Ciobanu G, Samide A. Thermogravimetric analysis of plant water content in relation with heavy metal stress. Journal of Thermal Analysis and Calorimetry. 2013 Feb 1;111(2):1139-47. https://doi.org/10.1007/s10973012-2239-0

[42] Kyewalyanga M. Phytoplankton primary production [Internet]. Regional State of the Coast Report. 2016 Sep. [cited 2019 Nov 22]. Available from: https://wedocs.unep.org/bitstream/handle/20.500.1182
2/11349/rsocr_printedition.compressed_Part16.pdf?se quence $=17 \&$ is Allowed $=\mathrm{y}$

[43] Basu S, Mackey KRM. Phytoplankton as key mediators of the biological carbon pump: Their responses to a changing climate. Sustainability. 2018 Mar;10(3):869. https://doi.org/10.3390/su10030869

[44] Bidle KD, Falkowski PG. Cell death in planktonic, photosynthetic microorganisms. Nature Reviews Microbiology. 2004 Aug;2:643-55. https://doi.org /10.1038/nrmicro956

[45] Sansone C, Galasso C, Orefice I, Nuzzo G, Luongo E, Cutignano A, et al. The green microalga Tetraselmis suecica reduces oxidative stress and induces repairing mechanisms in human cells. Scientific Reports. 2017 Jan 24;7(1):1-2. https://doi.org/10.1038/srep41215

[46] Stukenberg D, Zauner S, Dell'Aquila G, Maier UG. Optimizing CRISPR/Cas9 for the diatom Phaeodactylum tricornutum. Frontiers in Plant Science. 2018 Jun 6;9:740. https://doi.org/10.3389/ fpls.2018.00740

[47] Cai XH, Brown C, Adhiya J, Traina SJ, Sayre RT. Growth and heavy metal binding properties of transgenic Chlamydomonas expressing a foreign metallothionein gene. International Journal of Phytoremediation. 1999;1(1):53-65. https://doi.org /10.1080/15226519908500004

[48] Ansari TM, Marr IL, Tariq N. Heavy metals in marine pollution perspective - A mini review. Journal of Applied Science. 2004 Jan;4(1):1-20. https://doi.org /10.3923/jas.2004.1.20

[49] Levine I, Fleurence J. Microalgae in health and disease prevention. Elsevier, Academic Press; 2018.

[50] Zhang J, Zhou F, Chen C, Sun X, Shi Y, Zhao H, et al. Spatial distribution and correlation characteristics of heavy metals in the seawater, suspended particulate matter and sediments in Zhanjiang Bay, China. PLoS ONE. 2018;13(8). https://doi.org/10.1371/journal. pone.0201414

[51] Chakraborty S, Owens G. Metal distributions in seawater, sediment and marine benthic macroalgae from the South Australian coastline. International Journal of Environmental Science and Technology. 2014 Jul 1;11(5):1259-70. https://doi.org/10.1007/ s13762-013-0310-4

[52] Singh RN, Sharma S. Development of suitable photobioreactor for algae production - A review. Renewable and Sustainable Energy Reviews. 2012 May 1;16(4):2347-53. https://doi.org/10.1016/j.rser. 2012.01.026

[53] Flynn KJ, Greenwell HC, Lovitt RW, Shields RJ. Selection for fitness at the individual or population levels: Modelling effects of genetic modifications in microalgae on productivity and environmental safety. Journal of Theoretical Biology. 2010 Apr 7;263(3): 269-80. https://doi.org/10.1016/j.jtbi.2009.12.021 
UNDERGRADUATE RESEARCH IN NATURAL AND CLINICAL SCIENCE AND TECHNOLOGY (URNCST) JOURNAL Read more URNCST Journal articles and submit your own today at: https://www.urncst.com

\section{Article Information}

Managing Editor: Jeremy Y. Ng

Peer Reviewers: Jordan Donders, Janice Tai

Article Dates: Received Jan 26 20; Accepted Mar 23 20; Published Apr 2120

\section{Citation}

Please cite this article as follows:

$\mathrm{Xu}$ J, Soni V, Chopra M, Chan O. Genetic Modification of the HSP90 Gene Using CRISPR-Cas9 to Enhance

Thermotolerance in T. Suecica. URNCST Journal. 2020 Apr 21: 4(4). https://urncst.com/index.php/urncst/article/view/178

DOI Link: https://doi.org/10.26685/urncst.178

\section{Copyright}

(C) Joy Xu, Vedish Soni, Meera Chopra, Olsen Chan. (2020). Published first in the Undergraduate Research in Natural and Clinical Science and Technology (URNCST) Journal. This is an open access article distributed under the terms of the Creative Commons Attribution License (https://creativecommons.org/licenses/by/4.0/), which permits unrestricted use, distribution, and reproduction in any medium, provided the original work, first published in the Undergraduate Research in Natural and Clinical Science and Technology (URNCST) Journal, is properly cited. The complete bibliographic information, a link to the original publication on http://www.urncst.com, as well as this copyright and license information must be included.

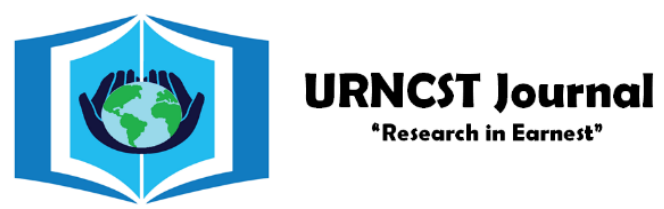

\section{Funded by the Government of Canada}

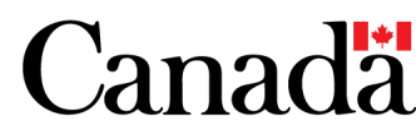

Do you research in earnest? Submit your next undergraduate research article to the URNCST Journal!

| Open Access | Peer-Reviewed | Rapid Turnaround Time | International | | Broad and Multidisciplinary | Indexed | Innovative | Social Media Promoted |

Pre-submission inquiries? Send us an email at info@urncst.com | Facebook, Twitter and LinkedIn: @URNCST

Submit YOUR manuscript today at https://www.urncst.com! 